\title{
Psychological and Sociodemographic Predictors of Fertility Intention among Childbearing-Aged Women in Hamadan, West of Iran: An Application of the BASNEF Model
}

\author{
Khadijeh Bandehelahi', Sahar Khoshravesh ${ }^{2}$, Majid Barati ${ }^{3, *}$, Leyli Tapak ${ }^{4}$ \\ 'Students Research Committee, Hamadan University of Medical Sciences, Hamadan, Iran \\ ${ }^{2}$ Department of Public Health, School of Health, Hamadan University of Medical Sciences, Hamadan, Iran \\ ${ }^{3}$ Social Determinants of Health Research Center, Hamadan University of Medical Sciences, Hamadan, Iran \\ ${ }^{4}$ Modeling of Noncommunicable Diseases Research Center, Hamadan University of Medical Sciences, Hamadan, Iran
}

\begin{abstract}
Background: Fertility and childbearing are the most important determinants of population variation around the world. This study was conducted with the aim of determining the psychological and sociodemographic factors predicting fertility intention among women referred to comprehensive health centers in Hamadan based on the beliefs, attitudes, subjective norms, and enabling factors (BASNEF) model.

Methods: This descriptive analytical study was performed in comprehensive health centers in Hamadan in 2016. Through a multi-stage sampling method, 484 women were enrolled in the study. The data collection tool was a selfreport questionnaire based on the constructs of the BASNEF model. Data were analyzed using linear regression, independent t-test, and a one-way analysis of variance using IBM SPSS software ver. 22.0 (IBM Corp., Armonk, NY, USA).

Results: The mean \pm standard deviation of the women's age was $31.85 \pm 6.13$ years. The variables of motivation to comply ( $\beta=0.228)$, enabling factors ( $\beta=0.162)$, subjective norms $(\beta=0.134)$, and attitude $(\beta=0.122)$ were the predictors of fertility intention in women. This model was able to explain $16.8 \%$ of variance in behavioral intention. Also, lower age, higher education, shorter duration of marriage, and having a daughter resulted in a greater fertility intention. Conclusion: It seems that designing and implementing educational programs to improve attitudes, promoting positive subjective norms, and enhancing enabling factors can play a major role in increasing fertility intention in women.
\end{abstract}

Keywords: Fertility; Intention; Women; Beliefs, Attitudes; Subjective Norms; Enabling Factors Model 


\section{INTRODUCTION}

In recent years, considerable demographic changes have occurred around the world, among which the changes in fertility rates are one.1) From the demographic perspective, fertility and childbearing are recognized as one of the most important determinants of population fluctuation, such that the demographic policies in most countries revolve around reducing or increasing fertility. ${ }^{2)}$ Childbearing is an important phenomenon in demographic change and the basis of sustainable development for countries with replacement fertility levels. ${ }^{3)}$ Reducing childbearing, in addition to having an impact on the population growth rate, can also affect the composition and structure of the population, such that there is a gradual shift from a younger to older age structure. ${ }^{4)}$ Iran is no exception when it comes to the process of population transition, and, in the last 30 years, the fertility rate has fallen below the succession level and progressed to a decline in childbearing. ${ }^{1)}$ The results of previous studies show that factors such as an increase in the age of marriage and that of the mother at the time of the first pregnancy, the broad coverage of contraceptive methods, gender equality, empowerment woman of low socioeconomic status, and changes in attitudes and fertility intentions have been effective in changing fertility behavior. ${ }^{5,6)}$ Attitude and fertility inclinations play a major role in childbearing, ${ }^{7)}$ positive attitudes toward childbearing can not only result in childbearing but also positive attitudes toward childbearing can not only result in timely childbearing but also elicit strong childbearing intentions. ${ }^{8)}$

In order to create positive beliefs in the community, there is a need for educational interventions tailored to existing needs. However, some scholars believe that the failure of some programs is due to the lack of attention to etiological studies and the fact that their design did not account for psychosocial models as a specific conceptual framework. ${ }^{9)}$ Therefore, the implementation of behavioral models seems to be effective in this regard; for this purpose, in this study, the beliefs, attitudes, subjective norms, and enabling factors (BASNEF) model was used (Figure 1).

This model, presented by Hubley ${ }^{10)}$ in 1988, consists of the structures of behavioral beliefs (individual beliefs about outcomes or attributes of performing the behavior), attitudes (a person's overall favorableness or unfavorableness toward performing the behavior), subjective norms (important referent individuals approving or disapproving of performing the behavior), enabling factors (antecedents to behav- ioral or environmental change that allow a motivation or environmental policy to be realized), and behavioral intention (perceived likelihood of performing the behavior). ${ }^{11)}$

This model has been derived by combining two models-PRECEDE and Reasoned Action - and has been implemented to study the behavior in question, create a design for changing it, and to determine the factors that are effective in the decision making of individuals demonstrating the behavior.

In the BASNEF model, while each intention does not necessarily lead to behavior, there are factors, such as money, skill, and existing services, connecting intention and behavior; this is the main point of departure from the Reasoned Action model. ${ }^{7)}$ In order to better understand the issue of childbearing, it is necessary to investigate women's beliefs regarding the subject; thus, based on the BASNEF model, this study aimed to investigate the psychological and sociodemographic factors related to the childbearing intention of women referred to comprehensive health centers in Hamadan.

\section{METHODS}

This was a descriptive analytical study conducted on 486 women referred to comprehensive health centers in Hamadan and selected by multi-stage sampling in 2017. For sampling, three clusters (health centers) from each of the four areas of Hamadan were randomly selected. Then, 3 days of the week were randomly chosen for visits to these health centers, where women were randomly selected. Inclusion criteria were women who were (1) 15-49 years old, (2) residing in the city, and (3) at least in the second year of marriage and with no children and those whose last child was born more than 3 years previously. The exclusion criterion was the unwillingness to participate in the study. Written informed consent was obtained from all participants. This study was also approved by the Ethics Committee of Hamadan University of Medical Sciences (approval no., IR.UMSHA.REC.1396.210).

The data collection tool was a researcher-made questionnaire based on the BASNEF model (Supplement 1), divided into two parts. The first was related to demographic information (mother's age, mother's occupation, mother's educational level, mother's religion, the age at which the current marriage took place, husband's age, husband's occupation, husband's educational level, husband's income, number of pregnancies, current number of children, number of live births, sex of the children, and the number of children the mother considered ide-

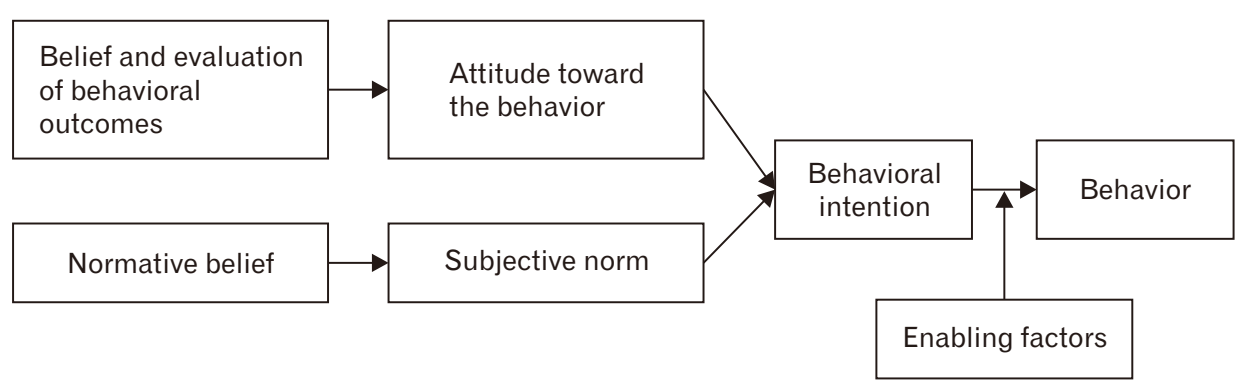

Figure 1. Framework of BASNEF (beliefs, attitudes, subjective norms, and enabling factors) model. 
al). The second part consisted of 50 items: 13 questions to assess attitude ("I feel happy in marital life because of the child"), 13 questions on subjective norms ("My husband encourages me to have a child"), 13 questions on motivation to comply ("My husband's opinion about childbearing is very important to me"), four questions on behavioral intention (perceived likelihood of childbearing over a given period of time; the next few years, for example), and seven questions on enabling factors ("Have you ever participated in childbearing skills classes?").

Questionnaire items were classified on a 5-point Likert scale (strongly disagree $=1$ to strongly agree $=5$ ). The content and face validity of the questionnaire were reviewed and verified by 10 health education professionals. For this purpose, the content validity ratio of 0.85 and the content validity index for the criteria of simplicity, specificity, and clarity were obtained, with an average of 0.90 . Cronbach's alpha coefficients were calculated to determine the reliability of various parts of the questionnaire: $0.70,0.79,0.49,0.85$, and 0.63 for the structures of attitude, subjective norms, motivation to comply, behavioral intention, and enabling factors, respectively. Data analysis was performed using IBM SPSS software ver. 22.0 (IBM Corp., Armonk, NY, USA). Descriptive statistics (charts, tables, and numerical indices) were used to describe the data. Inferential statistics (independent t-test, one-way analysis of variance, and linear regression) were used to determine the relationships between variables, and the significance level was set at less than 0.05 .

\section{RESULTS}

The mean \pm standard deviation of the age of the participants in the study was $31.85 \pm 6.13$ years and their age ranged between 16 and 49 years. Among the participants, $46.1 \%$ had university-level education and more than one-third (35.3\%) had been married for 5-10 years. Of these, $34.4 \%$ of women had one child. Demographic characteristics and fertility records are depicted in Table 1.

Statistical indicators of the structures of the BASNEF model in relation to childbearing showed that positive attitudes toward childbearing, with $65.6 \%$ of the maximum achievable scores, had the highest frequency. At the other end of the spectrum, behavioral intention, with $34.1 \%$ of the maximum achievable scores, had the lowest frequency. In other words, in this study, the attitude toward childbearing was relatively favorable among mothers. However, the fertility intention was not favorable. Also, among the structures of the BASNEF model, subjective norms had the highest correlation coefficient with behavioral intention ( $\mathrm{r}=0.351)$. As seen, there were positive (direction) relationships between all constructs of the BASNEF model and fertility intention $(\mathrm{P}<0.05)$ (Table 2).

There was a significant relationship between the behavioral intention of childbearing and age, education, income status, duration of marriage, and sex of the child $(\mathrm{P}<0.05)$. Using post hoc tests, it was detected that lower age, higher education, shorter duration of marriage,

Table 1. Summary statistics for characteristics of study participants $(\mathrm{N}=484)$

\begin{tabular}{|c|c|}
\hline Characteristic & Frequency (\%) \\
\hline \multicolumn{2}{|l|}{ Age (y) } \\
\hline$<20$ & $2(0.4)$ \\
\hline $21-30$ & 101 (20.9) \\
\hline $31-40$ & $272(56.2)$ \\
\hline $41-50$ & 109 (22.5) \\
\hline \multicolumn{2}{|l|}{ Educational status } \\
\hline Illiterate & $6(1.2)$ \\
\hline Primary & $52(10.7)$ \\
\hline Secondary & $203(41.9)$ \\
\hline Academic & $223(46.1)$ \\
\hline \multicolumn{2}{|l|}{ Job status } \\
\hline Housewife & 375 (79.5) \\
\hline Employed & 99 (20.5) \\
\hline \multicolumn{2}{|l|}{ Income status } \\
\hline Good & $160(33.1)$ \\
\hline Moderate & 277 (57.2) \\
\hline $\mathrm{Bad}$ & $47(9.7)$ \\
\hline \multicolumn{2}{|c|}{ Duration of marriage $(\mathrm{y})$} \\
\hline$<5$ & $129(26.7)$ \\
\hline $5-10$ & $171(35.3)$ \\
\hline $11-15$ & 99 (20.5) \\
\hline$>15$ & 85 (17.6) \\
\hline \multicolumn{2}{|l|}{ Gravida } \\
\hline No pregnancy & 80 (16.5) \\
\hline 1 Child & $152(31.4)$ \\
\hline 2 Children & $150(31.0)$ \\
\hline 3 Children & $59(12.2)$ \\
\hline >3 Children & $43(8.8)$ \\
\hline \multicolumn{2}{|l|}{ Sex of children } \\
\hline Boy & $164(33.9)$ \\
\hline Girl & $137(28.3)$ \\
\hline Boy and girl & $86(17.8)$ \\
\hline No children & $97(20.0)$ \\
\hline
\end{tabular}

Table 2. Descriptive statistics and intercorrelations between the BASNEF (beliefs, attitudes, subjective norms, and enabling factors) model constructs ( $N=484$ )

\begin{tabular}{|c|c|c|c|c|c|c|c|c|}
\hline Variable & Attitude & $\begin{array}{l}\text { Subjective } \\
\text { norms }\end{array}$ & $\begin{array}{l}\text { Motivation to } \\
\text { comply }\end{array}$ & $\begin{array}{l}\text { Enabling } \\
\text { factors }\end{array}$ & $\begin{array}{l}\text { Fertility } \\
\text { intention }\end{array}$ & $\begin{array}{l}\text { Mean } \pm \text { standard } \\
\text { deviation }\end{array}$ & $\begin{array}{l}\text { Range of } \\
\text { scores }\end{array}$ & Mean (\%) \\
\hline 1. Attitude & 1 & $0.195^{\star \star}$ & $0.165^{\star \star}$ & $0.166^{\star \star}$ & $0.209^{\star *}$ & $47.11 \pm 7.1$ & $13-65$ & 65.6 \\
\hline 2. Subjective norms & & 1 & $0.897^{\star \star}$ & $0.099^{*}$ & $0.351^{\star \star}$ & $72.20 \pm 17.4$ & $26-130$ & 44.4 \\
\hline 3. Motivation to comply & & & 1 & 0.015 & $0.310^{\star \star}$ & $35.66 \pm 11.8$ & $13-65$ & 43.6 \\
\hline 4. Enabling factors & & & & 1 & $0.210^{\star \star}$ & $12.87 \pm 3.1$ & $7-21$ & 41.9 \\
\hline 5. Fertility intention & & & & & 1 & $9.59 \pm 4.6$ & $4-20$ & 34.9 \\
\hline
\end{tabular}

${ }^{*} \mathrm{P}<0.05 .{ }^{* *} \mathrm{P}<0.01$. 
Table 3. Association between fertility intention and demographic variables ( $N=484)$

\begin{tabular}{|c|c|c|}
\hline Variable & Mean \pm standard deviation & P-value ${ }^{\star}$ \\
\hline Age (y) & & $<0.001$ \\
\hline$<20$ & $12.31 \pm 3.9$ & \\
\hline $21-30$ & $10.83 \pm 4.2$ & \\
\hline $31-40$ & $8.64 \pm 4.5$ & \\
\hline $41-50$ & $7.16 \pm 4.6$ & \\
\hline Educational status & & 0.013 \\
\hline Illiterate & $7.17 \pm 4.1$ & \\
\hline Primary & $8.04 \pm 4.5$ & \\
\hline Secondary & $9.47 \pm 4.6$ & \\
\hline Academic & $10.13 \pm 4.5$ & \\
\hline Job status & & 0.908 \\
\hline Housewife & $9.61 \pm 4.6$ & \\
\hline Employed & $9.55 \pm 4.4$ & \\
\hline Income status & & 0.698 \\
\hline Good & $9.78 \pm 4.5$ & \\
\hline Moderate & $9.56 \pm 4.6$ & \\
\hline $\mathrm{Bad}$ & $9.15 \pm 4.6$ & \\
\hline Duration of marriage (y) & & $<0.001$ \\
\hline$<5$ & $11.43 \pm 3.8$ & \\
\hline $5-10$ & $10.21 \pm 4.6$ & \\
\hline $11-15$ & $8.18 \pm 4.5$ & \\
\hline$>15$ & $7.20 \pm 4.2$ & \\
\hline Gravida & & $<0.001$ \\
\hline No pregnancy & $12.44 \pm 2.9$ & \\
\hline 1 Child & $10.44 \pm 4.4$ & \\
\hline 2 Children & $8 \pm 4.6$ & \\
\hline 3 Children & $9.27 \pm 4.5$ & \\
\hline$>3$ Children & $7.30 \pm 4.1$ & \\
\hline Sex of children & & $<0.001$ \\
\hline Boy & $9.41 \pm 4.6$ & \\
\hline Girl & $9.54 \pm 4.7$ & \\
\hline Boy and girl & $7.44 \pm 4.1$ & \\
\hline No children & $12.59 \pm 2.9$ & \\
\hline
\end{tabular}

${ }^{*} \mathrm{P}<0.05$.

being childless, and having a daughter resulted in a greater fertility intention (Table 3).

Linear regression analysis demonstrated that the variables of motivation to comply ( $\beta=0.228)$, enabling factors $(\beta=0.162)$, subjective norms $(\beta=0.134)$, and attitude $(\beta=0.122)$ were predictors of childbearing intention, in this order. Regarding the standardized values of beta, motivation to comply was the most powerful predictor compared to other structures of the model, which identified $16.8 \%$ of the variance of childbearing intention. According to the table, all the predictors had a significant positive (direct) impact on fertility intention $(\mathrm{P}<0.05)$. Therefore, by increasing one unit in attitude, the average of fertility intention increases by 0.122 units (Table 4 ).

\section{DISCUSSION}

The purpose of the present study was a BASNEF model-based investigation of the factors related to childbearing intention in women referred to comprehensive health centers in Hamadan. The results of this study demonstrated that all variables of the BASNEF model had a
Table 4. Linear regression analyses predicting fertility intention based on BASNEF (beliefs, attitudes, subjective norms, and enabling factors) model constructs ( $N=484$ )

\begin{tabular}{lcccrc}
\hline \multicolumn{1}{c}{ Variable } & $\beta$ & $\mathrm{B}^{*}$ & $\begin{array}{c}\text { Standard } \\
\text { error }\end{array}$ & P-value & $\begin{array}{c}\text { Adjusted } \\
R^{2}\end{array}$ \\
\hline Attitude & 0.122 & 0.079 & 0.028 & 0.005 & 0.168 \\
Subjective norms & 0.134 & 0.072 & 0.028 & 0.005 & \\
Motivation to comply & 0.228 & 0.088 & 0.018 & $<0.001$ & \\
Enabling factors & 0.162 & 0.236 & 0.062 & $<0.001$ & \\
\hline
\end{tabular}

*Unstandardized regression coefficient.

significant relationship with childbearing intention and were able to explain a total of $16.8 \%$ of the childbearing intention. Among the variables of the BASNEF model, the most influential predictor of childbearing intention in women was the motivation to obey. Other powerful variables were enabling factors, attitudes, and subjective norms.

In the present study, the motivation to comply was more influential for childbearing intention than other structures of the BASNEF model. Indeed, in this structure, it was determined that the opinions of important people, such as husband, father, father-in-law, mother-in-law, friends, and clerics play a very big role in a woman performing a particular behavior (such as childbearing) ${ }^{10}$ ) If a woman is exposed to the views of each of these people, her desire for childbearing will be affected. In Iranian culture, the desire for fertility, in addition to individual motivations, is also affected by social interactions, such that even if a couple is not interested in starting a family, the social pressure created by acquaintances puts them on the path to childbearing. ${ }^{2)}$

Another predictor of childbearing intention was enabling factors. According to the BASNEF model, when the attitude and subjective norms are conducive to a particular behavior, the behavioral intention leads to the desired behavior if the enabling factors serve as the mediator. ${ }^{10)}$ This has been confirmed in other studies, such that providing enabling factors like free-of-charge monthly pregnancy check-ups, free food coupons, tax cuts, paying the Bahar Azadi coin, giving student mothers more time to study, formulating plans to reduce working hours for employed mothers, providing 2-week paternity leave, increasing the leave for pregnant women, implementing encouraging policies for new mothers, and raising awareness about the importance of having children, have been able to influence childbearing intention and population growth. ${ }^{13)}$ The results of a study in Russia also showed that governmental incentives had a positive effect on childbearing. ${ }^{14)}$ Therefore, it is proposed that lawmakers focus on approving policies and passing laws that enable and support childbearing.

Other findings of the present study demonstrated that attitude and subjective norms also predict the intention of childbearing among women, which is consistent with the results of similar studies. ${ }^{7)}$ In fact, if a woman has a positive attitude toward childbearing and the important people in her life encourage her in this regard, it can significantly contribute to the woman's childbearing intention. ${ }^{15)}$ In some countries, religious beliefs regarding childbearing increase the intention to have children. ${ }^{16)}$ Therefore, it appears that this should be considered in designing interventions related to improving attitudes toward fertility 
in countries with a religious approach, for example, Iran.

In this study, younger women had higher childbearing intentions. While this finding is in agreement with one study, ${ }^{6}$ it contradicts another. ${ }^{17)}$ This contradiction appears to be explained by the fact that the quality of women's encounters with the issue of childbearing varies by age group, such that younger women have more motivation and patience and, consequently, have a greater tendency to become pregnant, but, at older ages, the focus on preventing pregnancy complications leads to a reduction in childbearing intention.

In the study, women with higher educational levels had higher childbearing intentions. This finding is inconsistent with previous studies conducted in Iran, ${ }^{18)}$ Oman, ${ }^{19)}$ and China. ${ }^{20)}$ In the mentioned studies, the reason for the lower fertility intention in women with higher educational levels was the fact that increasing the level of education increases women's willingness to participate in economic and social activities, which serves as a deterrent for childbearing intention. It seems that the contradiction between the present results and those of previous studies is due to the fact that although women with higher education tend to have higher childbearing intention, they may not always be able to convert it into childbearing behavior because of their various commitments, academic and otherwise.

In the present study, women with higher income had higher childbearing intention. This was consistent with the results of a previous study. ${ }^{21)}$ The evidence indicates that economic issues, including worries about providing for children and securing their future and the fear of increasing the family's economic burden, are one of the most important reasons for women's unwillingness to become pregnant. ${ }^{22)}$ Considering this, it seems that families with higher income have more intention to childbearing owing to greater financial security and lack of concern about the costs associated with raising children.

Another finding of this study was that childless women had higher fertility intention. The evidence shows that having no child, the probability of childbearing increases by 2.9 times and moreover, $77.7 \%$ of women with 2 or 3 children and $86 \%$ of women with more than three children did not intend to have another child. In fact, it can be said that the unwillingness to have children increases with the number of existing children. ${ }^{23)}$ It appears that fertility needs to be encouraged not only in childless women but also those who are already mothers.

In this study, higher childbearing tendencies were observed among the women with shorter marriage durations. In Iranian society, acquaintances tend to urge newly married couples to try for children and experience parenting. ${ }^{24)}$ In addition, it is a commonly held belief that having a child soon after marriage leads to greater stability in marital life. ${ }^{25)}$ It seems that such expectations and beliefs increase couples' childbearing tendencies. In this study, childbearing intention was observed to be greater among women who had daughters. In fact, the desire to have a son can affect fertility intention. Although this finding has been confirmed in a study in Pakistan, ${ }^{26)}$ it was necessary to confirm this in light of the cultural and social differences between populations. ${ }^{27)}$ Even in Iranian society, with its traditional culture, having a boy is more desirable. ${ }^{28)}$
The determination of factors related to childbearing intention among couples using the theories of health behavior is a strength of this study. Now, further studies are needed to assess the validity of other socio-psychological theories. However, the present study also had some limitations. The first limitation of the study was its cross-sectional nature; it is possible that causal relations between the variables could be further understood in a study conducted over a longer period of time. The second limitation was some eligible mothers' refusal to participate in the study. Finally, the use of a self-report measure might have led to response bias.

The results of this study indicate that designing and implementing educational programs to improve attitudes, promote positive subjective norms, and strengthen enabling factors can play a major role in increasing women's fertility intention.

\section{CONFLICT OF INTEREST}

No potential conflict of interest relevant to this article was reported.

\section{ACKNOWLEDGMENTS}

This work was supported by the Vice-chancellor for Research and Technology, Hamadan University of Medical Sciences under grant (grant no., 9603091542).

\section{SUPPLEMENTARY MATERIALS}

Supplementary material can be found via https://doi.org/10.4082/ kjfm.18.0008.

\section{ORCID}

Khadijeh Bandehelahi: https://orcid.org/0000-0003-3175-1643

Sahar Khoshravesh: https://orcid.org/0000-0003-1629-1386

Majid Barati: https://orcid.org/0000-0002-5152-1928

Leyli Tapak: https://orcid.org/0000-0002-4378-3143

\section{REFERENCES}

1. Haghdoost AA, Safari-Faramani R, Baneshi MR, Dehnavieh R, Dehghan M. Exploring perceptions of policymakers about main strategies to enhance fertility rate: a qualitative study in Iran. Electron Physician 2017;9:5568-77.

2. Frejka T, Gietel-Basten S, Abolina L, Abuladze L, Aksyonova S, Akrap A, et al. Fertility and family policies in Central and Eastern Europe after 1990. Comp Popul Stud 2016;41:3-56.

3. Castanheira HC, Kohler HP. Social determinants of low fertility in brazil. J Biosoc Sci 2017;49(S1):S131-S55.

4. Barro RJ, Lee JW. A new data set of educational attainment in the world, 1950-2010. J Dev Econ 2013;104:184-98.

5. Mills M, Rindfuss RR, McDonald P, te Velde E; ESHRE Reproduction and Society Task Force. Why do people postpone parenthood?: rea- 
sons and social policy incentives. Hum Reprod Update 2011;17:84860.

6. Schleutker E. Determinants of childbearing: a review of the literature. Zeitschrift für Soziologie 2014;43:192-211.

7. Brauner-Otto SR. Attitudes about children and fertility limitation behavior. Popul Res Policy Rev 2013;32:1-24.

8. Mitchell D, Gray E. Declining fertility: intentions, attitudes and aspirations. J Sociol 2007;43:23-44.

9. Simbar M, Ramezani Tehrani F. Sexual-reproductive health belief model of college students. Iran South Med J 2004;7:70-8.

10. Hubley J. Understanding behaviour: the key to successful health education. Trop Doct 1988;18:134-8.

11. Glanz K, Rimer BK, Viswanath K. Health behavior and health education: theory, research, and practice. 4th ed. San Francisco (CA): John Wiley \& Sons; 2008.

12. Khadivzadeh T, Latifnejad Roudsari R, Bahrami M, Taghipour A, Abbasi Shavazi J. The influence of social network on couples' intention to have the first child. Iran J Reprod Med 2013;11:209-18.

13. Pilten F, Rahmanian M. Sociological study of factors affecting willingness to childbearing women and married men. J Iran Soc Dev Stud 2015;7:122-34.

14. Andersson G. A study on policies and practices in selected countries that encourage childbirth: the case of Sweden. Rostock: Max Planck Institute for Demographic Research; 2005.

15. Dommermuth L, Klobas J, Lappegard T. Realization of fertility intentions by different time frames. Adv Life Course Res 2015;24:34-46.

16. Heywood W, Pitts MK, Patrick K, Mitchell A. Fertility knowledge and intentions to have children in a national study of Australian secondary school students. Aust N Z J Public Health 2016;40:462-7.

17. Sennott C, Yeatman S. Stability and change in fertility preferences among young women in Malawi. Int Perspect Sex Reprod Health 2012;38:34-42.

18. Tavousi M, Motlagh ME, Eslami M, Haerimehrizi A, Hashemi A, Montazeri A. Fertility desire and its correlates: a pilot study among married citizens living in Tehran, Iran. Payesh 2015;14:597-605.

19. Dorvlo AS, Bakheit CS, Al-Riyami A, Morsi M, Al-Adawi S. A study of fertility patterns of ever married women in oman. Sultan Qaboos Univ Med J 2006;6:33-40.

20. Zheng Y, Yuan J, Xu T, Chen M, Liang H, Connor D, et al. Socioeconomic status and fertility intentions among Chinese women with one child. Hum Fertil (Camb) 2016;19:43-7.

21. Pradhan A, Pandey S. Fertility desire of working women in Kathmandu. J Nepal Health Res Counc 2010;8:95-8.

22. Eshaghi M, Mohebi SF, Papynezhad SH, Jahandar Z. Childbearing challenges for working women: a qualitative study. Woman Dev Polit 2014;12:111-34.

23. Hosseini H, Bagi B. Study of fertility desires of Kurdish women in city of Mahabad. Women Strateg Stud (Ketabe Zanan) 2013;15:121-61.

24. Asgari A, Abbasi Shavazi MJ, Sadeghi R. Mothers, daughters and Marriage. Women Strateg Stud 2009;11:7-36.

25. Kazemipour SH. Iran and demographic factors that influence the evolution of marriage age. Res Women 2006;3:1.

26. Zaidi B, Morgan SP. In the pursuit of sons: additional births or sex-selective abortion in Pakistan? Popul Dev Rev 2016;42:693-710.

27. Almond D, Edlund L, Milligan K. Son preference and the persistence of culture: evidence from South and East Asian immigrants to Canada. Popul Dev Rev 2013;39:75-95.

28. Attaei Saeidi H. Evaluation of factors affecting family planning among married biased in Sardasht city. J Popul 2006;47:65-6. 


\section{Questionnaire}

\section{Demoghraphic variables}

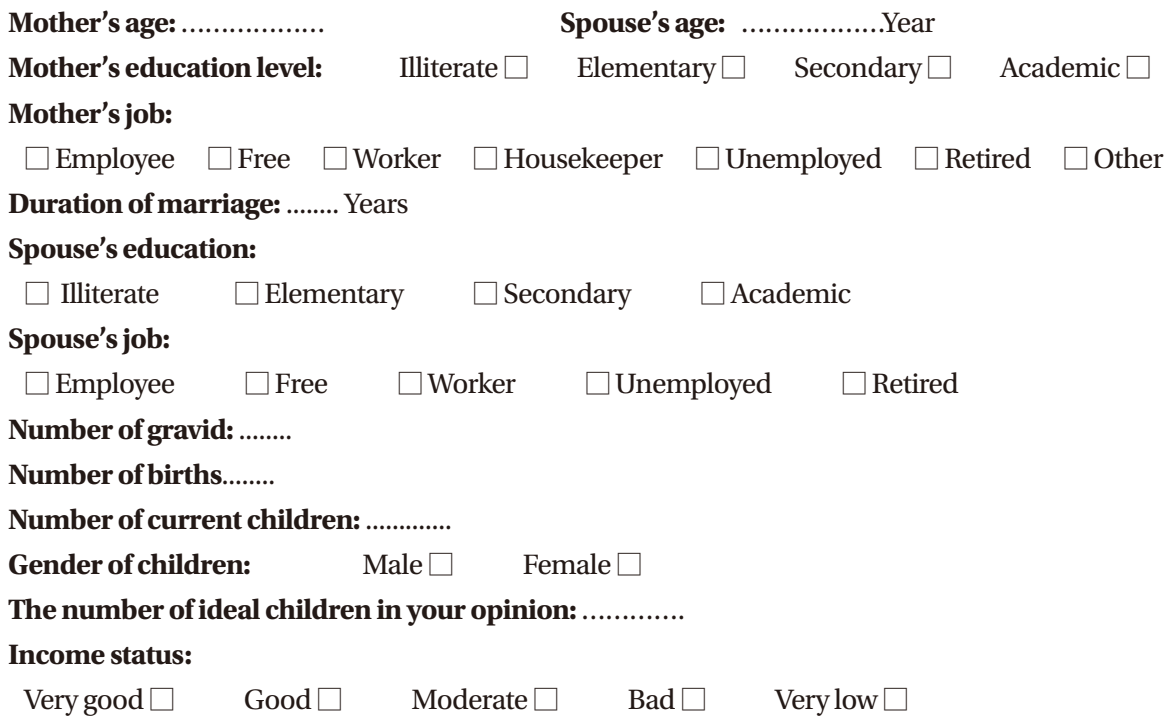

The number of ideal children in your opinion:

Income status:

Verygood $\square \quad$ Good $\square \quad$ Moderate $\square \quad \operatorname{Bad} \square \quad$ Verylow $\square$

\section{Part 1: Attitude toward childbearing}

B) Specify your opinion on the following questions by selecting one of the answers for each question with the $\times$ sign.

1. I feel happy with the kids in marital life.

$\begin{array}{lllllll}\text { Strongly disagree } & 1 & 2 & 3 & 4 & 5 & \text { Strongly agree }\end{array}$

2. Baby is a walking stick.

$\begin{array}{lllllll}\text { Strongly disagree } & 1 & 2 & 3 & 4 & 5 & \text { Strongly agree }\end{array}$

3. I think that kids need to live.

$\begin{array}{llllllll}\text { Strongly disagree } & 1 & 2 & 3 & 4 & 5 & \text { Strongly agree }\end{array}$

4. It is important for me to be alone in my first child.

$\begin{array}{lllllll}\text { Strongly disagree } & 1 & 2 & 3 & 4 & 5 & \text { Strongly agree }\end{array}$

5. I think that having children resulted to mental illness.

$\begin{array}{lllllll}\text { Strongly disagree } & 1 & 2 & 3 & 4 & 5 & \text { Strongly agree }\end{array}$

6. I consider the child as an obstacle to achieving social goals.

$\begin{array}{llllllll}\text { Strongly disagree } & 1 & 2 & 3 & 4 & 5 & \text { Strongly agree }\end{array}$

7. My husband and I find problem to continue my education.

$\begin{array}{llllllll}\text { Strongly disagree } & 1 & 2 & 3 & 4 & 5 & \text { Strongly agree }\end{array}$

8. Having children resulted to make more problems.

$\begin{array}{llllllll}\text { Strongly disagree } & 1 & 2 & 3 & 4 & 5 & \text { Strongly agree }\end{array}$

9. I don't want to have a child because of fear of giving birth.

$\begin{array}{llllllll}\text { Strongly disagree } & 1 & 2 & 3 & 4 & 5 & \text { Strongly agree }\end{array}$

10. I hate large families.

$\begin{array}{lllllll}\text { Strongly disagree } & 1 & 2 & 3 & 4 & 5 & \text { Strongly agree }\end{array}$

11. Excessive children are a barrier to parents' success.

$\begin{array}{llllllll}\text { Strongly disagree } & 1 & 2 & 3 & 4 & 5 & \text { Strongly agree }\end{array}$

12. Given that I want to have son and daughter, I need to havinge a baby.

$\begin{array}{llllllll}\text { Strongly disagree } & 1 & 2 & 3 & 4 & 5 & \text { Strongly agree }\end{array}$

13. Having children resulted to reduct of fitness.

$\begin{array}{llllllll}\text { Strongly disagree } & 1 & 2 & 3 & 4 & 5 & \text { Strongly agree }\end{array}$




\section{Part 2: Questions about subjective norms (influential people):}

\section{A) Normative beliefs}

- How much do you encourage the following people to have a baby? (Please select an option).

1. My spouse

$\begin{array}{lllllll}\text { Very low } & 1 & 2 & 3 & 4 & 5 & \text { Very high }\end{array}$

2. My mother

$\begin{array}{lllllll}\text { Very low } & 1 & 2 & 3 & 4 & 5 & \text { Very high }\end{array}$

3. My father

$\begin{array}{lllllll}\text { Very low } & 1 & 2 & 3 & 4 & 5 & \text { Very high }\end{array}$

4. My father-in-law

$\begin{array}{lllllll}\text { Verylow } & 1 & 2 & 3 & 4 & 5 & \text { Very high }\end{array}$

5. My mother-in-law

$\begin{array}{lllllll}\text { Verylow } & 1 & 2 & 3 & 4 & 5 & \text { Very high }\end{array}$

6. My sister

$\begin{array}{lllllll}\text { Very low } & 1 & 2 & 3 & 4 & 5 & \text { Very high }\end{array}$

7. My brother

$\begin{array}{lllllll}\text { Very low } & 1 & 2 & 3 & 4 & 5 & \text { Very high }\end{array}$

8. My best friends

$\begin{array}{lllllll}\text { Very low } & 1 & 2 & 3 & 4 & 5 & \text { Very high }\end{array}$

9. My doctors

$\begin{array}{lllllll}\text { Very low } & 1 & 2 & 3 & 4 & 5 & \text { Very high }\end{array}$

10. My neighbors

$\begin{array}{lllllll}\text { Very low } & 1 & 2 & 3 & 4 & 5 & \text { Very high }\end{array}$

11. Health personnel

Very low

2

3

$4 \quad 5 \quad$ Very high

12. Clergies

$\begin{array}{lllllll}\text { Very low } & 1 & 2 & 3 & 4 & 5 & \text { Very high }\end{array}$

13. Mass media

Very low

2

3

$4 \quad 5 \quad$ Very high

\section{B) Motivation to comply:}

- Which of these people is more important in your desire for childbirth? (Please select an option).

1. My spouse

$\begin{array}{lllllll}\text { Very low } & 1 & 2 & 3 & 4 & 5 & \text { Very high }\end{array}$

2. My mother

$\begin{array}{lllllll}\text { Very low } & 1 & 2 & 3 & 4 & 5 & \text { Very high }\end{array}$

3. My father

$\begin{array}{lllllll}\text { Very low } & 1 & 2 & 3 & 4 & 5 & \text { Very high }\end{array}$

4. My father-in-law

$\begin{array}{lllllll}\text { Very low } & 1 & 2 & 3 & 4 & 5 & \text { Very high }\end{array}$

5. My mother-in-law

$\begin{array}{lllllll}\text { Very low } & 1 & 2 & 3 & 4 & 5 & \text { Very high }\end{array}$

6. My sister

$\begin{array}{lllllll}\text { Very low } & 1 & 2 & 3 & 4 & 5 & \text { Very high }\end{array}$

7. My brother

$\begin{array}{lllllll}\text { Very low } & 1 & 2 & 3 & 4 & 5 & \text { Very high }\end{array}$

8. My best friends

$\begin{array}{lllllll}\text { Very low } & 1 & 2 & 3 & 4 & 5 & \text { Very high }\end{array}$

9. My doctors

$\begin{array}{lllllll}\text { Very low } & 1 & 2 & 3 & 4 & 5 & \text { Very high }\end{array}$


10. My neighbors

$\begin{array}{lllllll}\text { Very low } & 1 & 2 & 3 & 4 & 5 & \text { Very high }\end{array}$

11. Health personnel

$\begin{array}{lllllll}\text { Very low } & 1 & 2 & 3 & 4 & 5 & \text { Very high }\end{array}$

12. Clergies

$\begin{array}{lllllll}\text { Very low } & 1 & 2 & 3 & 4 & 5 & \text { Very high }\end{array}$

13. Mass media Very low

2

3

$4 \quad 5 \quad$ Very high

\section{Part 3: Childbearing intention questions:}

Specify your opinion on the following questions by selecting one of the numbers for each question with the $\times$ sign.

1. I intend to have children in the next 3 months.

$\begin{array}{llllllll}\text { Strongly disagree } & 1 & 2 & 3 & 4 & 5 & \text { Strongly agree }\end{array}$

2. I intend to have children in the next 6 month.

$\begin{array}{llllllll}\text { Strongly disagree } & 1 & 2 & 3 & 4 & 5 & \text { Strongly agree }\end{array}$

3. I'm going to have a baby in the next year.

$\begin{array}{lllllll}\text { Strongly disagree } & 1 & 2 & 3 & 4 & 5 & \text { Strongly agree }\end{array}$

4. I intend to have a baby in the future.

$\begin{array}{llllllll}\text { Strongly disagree } & 1 & 2 & 3 & 4 & 5 & \text { Strongly agree }\end{array}$

\section{Part 4: Enabling factors questions:}

Answer the questions by selecting one of the answers to the question with the $\times$ sign.

1. Do you have participated at any child bearing skills's course?

$$
\text { Yes } \square \quad \text { Somewhat } \square \quad \text { No } \square
$$

2. Do you have enough time for child bearing?

Yes $\square \quad$ Somewhat $\square \quad$ No $\square$

3. Do you have appropriate economic conditions to keep your child?

$$
\text { Yes } \square \quad \text { Somewhat } \square \quad \text { No } \square
$$

4. Do you have any coverage of insurance related to child bearing facilities?

$$
\text { Yes } \square \quad \text { Somewhat } \square \quad \text { No } \square
$$

5. Do you think that free cost of normal vaginal delivery resulted to encourage childbirth?

$$
\text { Yes } \square \quad \text { Somewhat } \square \quad \text { No } \square
$$

6. Do your staff provide educational pamphlets and brochures related to child-rearing for you?

$$
\text { Yes } \square \quad \text { Somewhat } \square \quad \text { No } \square
$$

7. I intend to have children in order to take the government's encouraging policie.

$$
\text { Yes } \square \quad \text { Somewhat } \square \quad \text { No } \square
$$

